\title{
Characterization of self-reported communication disorders in elderly women living in Manaus, state of Amazonas, Brazil
}

\author{
Caracterização dos distúrbios de comunicação autorreferidos em idosas residentes de \\ Manaus-AM, Brasil
}

Abstract

Objectives: Characterize self-reported communication disorders highlighting the association between variables of health conditions, socio-demographic factors, lifestyle, hearing loss and diseases in an elderly group. Methods: Cross-sectional study conducted from August to December 2012, with 159 women aged 60 or more, recruited at UnATI/UEA (University of the Third Age, University of the State of Amazonas), Manaus, Amazonas State, Brazil. The subjects were interviewed and asked for selfreported communications disorders. Descriptive analysis was performed using central tendency and dispersion measures for continuous variables and frequency distributions for categorical variables and the prevalence of self-reported language disorders was estimated. To verify the presence of statistically significant differences it was used $\chi^{2}$, considering the significance level of $5 \%(\mathrm{p} \leq 0.05)$. Results: Communication disorders were reported by $8.18 \%$ of elderly women. The following deficits were reported: intelligibility (6.92\%), oral comprehension (10.69\%), lexical access (10.69\%), and recent memory $(38.36 \%)$. Reading and writing difficulties were informed by $5.66 \%$ and $6.92 \%$, respectively. Among the illiterate group, 20\% declared communication disorders, while the literate group, $8.44 \%$. Statistical association was verified between communication disorders and self-reported hearing loss $(\mathrm{p}=0.03)$. Association was not detected between communication disorders and diseases. Conclusions: Considering the diversity of communication disorders within this population, further studies are needed to assess if changes occur at the aging process and how they work so that possibilities for prevention can be discussed.

\footnotetext{
Instituto Leônidas e Maria Deane. Fundação Oswaldo Cruz. Manaus, AM, Brasil

Escola Nacional de Saúde Pública Sérgio Arouca. Fundação Oswaldo Cruz. Rio de Janeiro, RJ, Brasil.

Universidade Aberta da Terceira Idade. Universidade do Estado do Amazonas. Manaus, AM, Brasil.
}

Apoio financeiro: Fundação de Amparo a Pesquisa do Amazonas (FAPEAM), projeto Universal 21/2011, processo no 062.03095/2012.

Correspondência / Correspondence

Karla Geovanna Moraes Crispim

E-mail:karlag_crispim@hotmail.com
Karla Geovanna Moraes Crispim? Aldo Pacheco Ferreira ${ }^{2}$ Terezinha Lima Silva ${ }^{3}$ Euler Esteves Ribeiro ${ }^{3}$

Key words: Elderly. Health Profile. Public Health.

Communication Disorders. 


\section{Resumo}

Objetivo: Caracterizar distúrbios de comunicação autorreferidos, destacando a associação entre as variáveis "condição de saúde", "aspectos sociodemográficos", "estilo de vida", "perda auditiva" e "morbidades", num grupo de idosas. Métodos: Estudo seccional realizado de agosto a dezembro de 2012, com 159 mulheres com 60 anos de idade ou mais, matriculadas na UnATI/UEA (Universidade da Terceira Idade da Universidade do Estado do Amazonas), Manaus-AM, Brasil. As participantes foram entrevistadas e questionadas sobre desordens de comunicação autorreferidas. Realizou-se análise descritiva por meio de medidas de tendência central e de dispersão para as variáveis contínuas e de distribuições de frequência para as variáveis categóricas e foram estimadas as prevalências das desordens de linguagem autorreferidas. Para verificar a presença de diferenças estatisticamente significativas, foi utilizado $\chi^{2}$, considerando nível de significância 5\% ( $\left.\mathrm{p} \leq 0,05\right)$. Resultados: O déficit de comunicação foi referido por $8,18 \%$ das idosas. Foram relatadas dificuldades de inteligibilidade (6,92\%); compreensão oral (10,69\%); acesso ao léxico (10,69\%); e memória recente $(38,36 \%)$. No domínio de leitura e escrita, referiram dificuldade $5,66 \%$ e $6,92 \%$, respectivamente. Entre os analfabetos, $20 \%$ relataram dificuldades de comunicação, enquanto os alfabetizados, 8,44\%. Observou-se associação entre dificuldade de comunicação e perda auditiva autorreferida $(\mathrm{p}=0,03)$. Não se observou tal associação com as morbidades mais prevalentes. Conclusões: Considerando a diversidade de alterações na linguagem dessa população, são necessários mais estudos que avaliem se há mudanças decorrentes do processo de envelhecimento e como estas se caracterizam, para que se possa discutir possibilidades de prevenção.

\section{Palavras-chave:}

Envelhecimento. Perfil de Saúde. Saúde Pública. Transtornos da Comunicação.

\section{INTRODUCTION}

Communication is an essential activity in the life of the human beings, as it allows establishing social bonds, interaction, knowledge acquisition, expression, comprehension and information exchange, helping increase autonomy, independence and well-being. ${ }^{1}$

The act of communication involves sensorial, motor, cognitive and linguistic abilities, and any limitation that affects one of these parameters may impair language functionality. ${ }^{2}$ Although communication disorders can affect people of any age, deficits are observed with increasing age, resulting from organic and functional changes that occur in the natural aging process. ${ }^{3,4}$ However, studies of linguistics and communicative manifestations of elderly describe, mostly, the sequelaes of pathological processes, and there are few investigations describing the language of healthy elderly.
Changes in language performance have been noticed in healthy elderly, however, these facts are not significant unless they are related to other pathological processes. ${ }^{2,6,7}$ Decline, when it occurs, seems to be not homogeneous, and preserve some aspects, while others are modified. ${ }^{8}$

In Brazil, there are few epidemiological studies that characterize the language of healthy elderly. Considering the diversity it presents in this age group, with many controversies and questions, beyond the inherent difficulties of evaluating the complex system that is language, this field shows lack of research. ${ }^{5}$ The need to describe and analyze these events, in order to establish a threshold between natural and pathological process of aging communication has been emphasized. ${ }^{5,8,9}$ Addressing the communication functionality of the elderly may arise more consistent information about these events, increasing the possibilities for prevention. 
Therefore, this study aimed to characterize the disorders of self-reported communication (evoked memory, oral and written comprehension, reading and written knowledge, lexical access, speech intelligibility, oral production and spontaneous repetition and hearing loss) highlighting the association between the variables of health condition, socio-demographic aspects, lifestyle, hearing loss and morbidity in a group of elderly women enrolled in UnATI/ UEA (Universidade da Terceira Idade da Universidade do Estado do Amazonas), in the city of Manaus, Amazon state, Brazil.

\section{MATERIALS AND METHODS}

\section{Study design}

A cross-sectional study was conducted with 159 elderly women, aged 60 and over, enrolled in the University of Third Age - UnATI/UEA, in Manaus, state of Amazonas, from August to December 2012. The study was developed based on data from a survey that estimated the prevalence of osteoporosis in 249 women attending the University. This explains the sample being composed only by elderly women. The inclusion criterion for the study in question was the age of 60 years or more, which resulted in 159 participants.

Face-to-face interviews were based on structured questionnaires. Information was obtained through a questionnaire consisting of closed questions mostly, organized in thematic groups: socioeconomic status, health status, physical activity, heath condition, morbid profile, nutritional status and dietary habits, functional evaluation, cognition and mood, language evaluation and self-reported hearing. The instrument was developed by the UnATI team to meet the overall objective of the study to estimate the prevalence of osteoporosis. Issues relating to language addressed the following items: evoked memory, oral comprehension and written language, reading and writing skills, lexical access, speech intelligibility, spontaneous oral production and repetition and finally selfreported hearing loss. The interviews were done by five trained interviewers, all of whom had graduate education. They had previously done field surveys and had experience of face-to-face interviews.

\section{Statistics}

Descriptive analysis of the study population was performed using measures of central tendency and dispersion for continuous variables, frequency distributions for categorical variables, and estimated the prevalence of self-reported communication disorders. To verify the presence of statistically significant differences between the study groups, were used $t$ test and $\chi^{2}$, considering a significance level of $5 \%(\mathrm{p} \leq 0.05)$. Statistical tests were performed using Epi InfoTM, version 7.

\section{Ethical aspects}

During preliminary meeting for the research, participants were introduced to the research proposal, received information about the procedures involved and were invited to participate. Participation in the study was formalized through the signing of the consent form. The research design was approved by the Ethics Committee in Research of Fiocruz's National School of Public Health Sergio Arouca (Ensp/Fiocruz - No 156/2011).

\section{RESULTS}

According to the interviewees residence address, the survey obtained data that revealed that the most researched participants were residents in the urban area of Manaus (figure 1). The south zone was more prevalent $(47.79 \%)$, as described on IBGE. ${ }^{10}$ This indicates a higher concentration of elderly people in the urban area of Manaus (figure 1). 


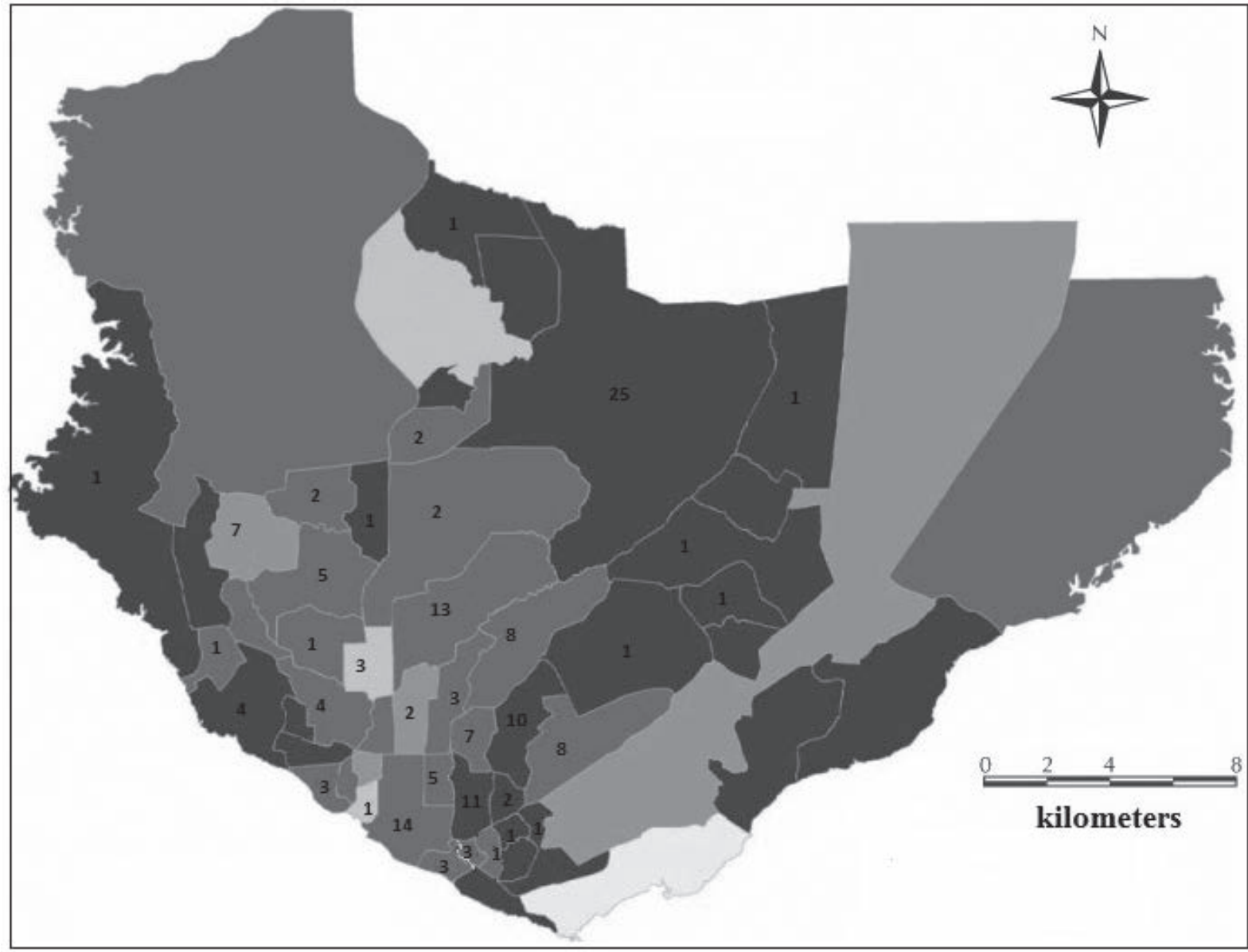

Figure 1. Distribution of respondents' residential address in Manaus among 159 elderly women participants in the survey (UnATI/UEA). Manaus-AM, 2012.

The higher predominance of interviewees $(55.98 \%)$ lived together and $79.88 \%$ in their own homes. The highest concentration of subjects was aged between 60 and 64 years $(41.51 \%)$ and mean age of 67.6 years, with $62.27 \%$ of schooling over eight years and $3.4 \%$ illiteracy. The income from one to two minimum salaries (58.49 $\%$ was more prevalent, mostly coming from retirement $(74.84 \%)$ and belonging to the low income $49.9 \%$, according to the classification of Inter-Union Department of Statistics and
Socioeconomic Studies. ${ }^{11}$ Socio-demographic data are presented in table 1 .

The profile of self-reported morbidities showed an average of 6.5 comorbidities, and the more prevalent were hypertension (52.20\%), dyslipidaemia (48.1\%), gastritis (28.9\%), arthrosis $(27.3 \%)$, thrombosis $(22.8 \%)$, arthritis $(17.2 \%)$, and diabetes $(18.87 \%)$. The functional assessment revealed that $94.7 \%$ of subjects were independent in activities of daily living. 
Table 1. Socio-demographic features of 159 elderly women. Manaus-AM, 2012.

\begin{tabular}{|c|c|}
\hline Variables & $\mathrm{n}(\%)$ \\
\hline \multicolumn{2}{|l|}{ Age (years) } \\
\hline $60-64$ & $66(41.51)$ \\
\hline $65-69$ & $44(27.67)$ \\
\hline $70-74$ & $21(13.21)$ \\
\hline $75-80$ & $19(11.95)$ \\
\hline$\geq 80$ & $9(5.66)$ \\
\hline \multicolumn{2}{|l|}{ Education (years completed) } \\
\hline Eight years or less & $60(37.73)$ \\
\hline More than eight years & $99(62.27)$ \\
\hline \multicolumn{2}{|l|}{ Income } \\
\hline Yes & $138(86.79)$ \\
\hline No & $21(13.21)$ \\
\hline \multicolumn{2}{|l|}{ Work activities } \\
\hline Yes & $16(10.07)$ \\
\hline No & $143(89.93)$ \\
\hline \multicolumn{2}{|l|}{ Source of income } \\
\hline Salary & $16(10.07)$ \\
\hline Retirement & $119(74.84)$ \\
\hline Pension & $3(1.88)$ \\
\hline Support from relatives & $21(13.21)$ \\
\hline \multicolumn{2}{|l|}{ Household income (minimum wage) } \\
\hline$<1$ & $20(12.58)$ \\
\hline $1-2$ & $93(58.49)$ \\
\hline $3-4$ & $28(17.61)$ \\
\hline $5-6$ & $14(8.8)$ \\
\hline$>6$ & $4(2.52)$ \\
\hline \multicolumn{2}{|l|}{ Residence } \\
\hline Rented & $15(9.43)$ \\
\hline Courtesy & $17(10.69)$ \\
\hline Own & $127(79.88)$ \\
\hline \multicolumn{2}{|l|}{ Live alone? } \\
\hline Yes & $70(44.02)$ \\
\hline No & $89(55.98)$ \\
\hline \multicolumn{2}{|l|}{ Family support? } \\
\hline Yes & $135(84.9)$ \\
\hline No & $24(15.1)$ \\
\hline
\end{tabular}


Table 2 provides the prevalence of self- The hardship or lexical access was $10.69 \%$. The reported communication deficits. The prevalence of communication disorder was $8.81 \%$, compromised intelligibility rate of $6.92 \%$, and the occurrence of incomprehension was $10.69 \%$. lack of reading and writing domain was observed in $5.66 \%$ and $6.92 \%$ of subjects, respectively. The prevalence of recent memory deficit was observed in $38.36 \%$.

Table 2. Prevalence of self-reported language aspects of 159 elderly women. Manaus-AM, 2012.

\begin{tabular}{|c|c|}
\hline Variables & $\mathrm{n}(\%)$ \\
\hline \multicolumn{2}{|l|}{ Difficulty in speech } \\
\hline Yes & $14(8.81)$ \\
\hline No & $143(89.9)$ \\
\hline Sometimes & $2(1.26)$ \\
\hline \multicolumn{2}{|l|}{ Intelligibility compromised } \\
\hline Yes & $11(6.92)$ \\
\hline No & $134(84.28)$ \\
\hline Sometimes & $12(7.55)$ \\
\hline \multicolumn{2}{|l|}{ Comprehension difficulty } \\
\hline Yes & $17(10.69)$ \\
\hline No & $107(67.30)$ \\
\hline Sometimes & $33(20.75)$ \\
\hline \multicolumn{2}{|l|}{ Difficulty for lexical access } \\
\hline Yes & $17(10.69)$ \\
\hline No & $114(71.70)$ \\
\hline Sometimes & $27(16.98)$ \\
\hline \multicolumn{2}{|l|}{ Domain reading } \\
\hline Yes & $141(88.68)$ \\
\hline No & $9(5.66)$ \\
\hline Sometimes & $9(5.66)$ \\
\hline \multicolumn{2}{|l|}{ Understanding of reading } \\
\hline Yes & 137(86.16) \\
\hline No & $7(8.18)$ \\
\hline Sometimes & $2(1.26)$ \\
\hline \multicolumn{2}{|l|}{ Domain writing } \\
\hline Yes & $143(89.9)$ \\
\hline No & $11(6.92)$ \\
\hline Sometimes & $5(3.14)$ \\
\hline \multicolumn{2}{|l|}{ Understanding of writing } \\
\hline Yes & $140(88.61)$ \\
\hline No & $9(5.7)$ \\
\hline Sometimes & $8(5.06)$ \\
\hline \multicolumn{2}{|l|}{ Spontaneous oral production } \\
\hline Yes & $146(91.82)$ \\
\hline No & $13(8.18)$ \\
\hline \multicolumn{2}{|l|}{ Memory deficit } \\
\hline Yes & $61(38.36)$ \\
\hline No & 98 (61.64) \\
\hline
\end{tabular}


There was no significant association between self-reported communication disorder and educational level $(\mathrm{p}=0.8024)$ but among the illiterate, $20 \%$ reported communication disorder, while in the group of literate, this number dropped to $8.44 \%$. There was no communication disorder associated with the most prevalent morbidities. The communication disorder was associated with hearing loss $(p=0.03)$. From the subjects who reported communication disorders, $35.71 \%$ denoted normal hearing, whereas in the group without communication difficulty, normal hearing was present in $72.73 \%$ (table 3).

With regard to the hearing loss, this survey was reported by $17.61 \%$ of interviewees. Table 4 presents data related to self-reported hearing.

Table 3. Prevalence of self-reported communication disorders on elderly women according to health status, linguistic and socio-demographics aspects. Manaus-AM, 2012.

\begin{tabular}{|c|c|c|c|}
\hline Variables & $\begin{array}{l}\text { Speaking difficulty (yes) } \\
\qquad \mathrm{n}=14\end{array}$ & $\begin{array}{l}\text { Speaking difficulty } \\
\text { (no) } n=143\end{array}$ & $\chi^{2}$ \\
\hline \multicolumn{4}{|l|}{ Age (years) } \\
\hline $60-64$ & $6(3.77)$ & $59(37.1)$ & \\
\hline $65-69$ & $5(3.14)$ & $38(23.90)$ & \\
\hline $70-74$ & $0(0)$ & $21(13.21)$ & \\
\hline $75-80$ & $1(0.63)$ & $20(12.58)$ & \\
\hline$\geq 80$ & $0(0)$ & $7(4.4)$ & \\
\hline $\begin{array}{c}\text { Education } \\
\text { Illiterate } \\
\text { Literate }\end{array}$ & $\begin{array}{c}1(20 \%) \\
13(8.44 \%)\end{array}$ & $\begin{array}{c}4(80 \%) \\
139(90.26)\end{array}$ & 0.6517 \\
\hline \multicolumn{4}{|l|}{ Hearing difficulty } \\
\hline Yes & $9(64.29 \%)$ & $5(35.71 \%)$ & \multirow{2}{*}{$>0.03$} \\
\hline No & $5(4.55 \%)$ & $104(94.55 \%)$ & \\
\hline \multicolumn{3}{|l|}{ Hypertension } & \multirow{3}{*}{0.6378} \\
\hline Yes & $9(10.84 \%)$ & $73(87.95 \%)$ & \\
\hline No & $5(6.58 \%)$ & $70(92.11 \%)$ & \\
\hline \multicolumn{3}{|l|}{ Diabetes } & \multirow{3}{*}{0.7691} \\
\hline Yes & $3(10 \%)$ & $27(90 \%)$ & \\
\hline No & $11(8.53 \%)$ & $116(89.92 \%)$ & \\
\hline \multicolumn{3}{|c|}{ Cerebrovascular accident } & \multirow{3}{*}{0.3564} \\
\hline Yes & $1(14.29 \%)$ & $6(85.71 \%)$ & \\
\hline No & $13(8.55 \%)$ & $137(90.13 \%)$ & \\
\hline \multicolumn{3}{|l|}{ Memory } & \multirow{4}{*}{1.3248} \\
\hline Yes & $9(9.18 \%)$ & $87(88.78 \%)$ & \\
\hline No & $5(8.2 \%)$ & $56(91.8 \%)$ & \\
\hline Sometimes & $2(2.04 \%)$ & $0(0 \%)$ & \\
\hline \multicolumn{3}{|l|}{ Lexical access } & \multirow{5}{*}{42.0587} \\
\hline Yes & $6(35.29 \%)$ & $11(64.71 \%)$ & \\
\hline No & $3(2.63 \%)$ & $111(97.37 \%)$ & \\
\hline Sometimes & $4(14.81 \%)$ & $21(77.78 \%)$ & \\
\hline Don't know & $1(7.14 \%)$ & $0(0 \%)$ & \\
\hline
\end{tabular}


Table 4. Data related to self-reported hearing of 159 elderly women. Manaus-AM, 2012.

\begin{tabular}{|c|c|c|c|}
\hline Self-reported hearing & Frequency & Percentage & Cumulative percentage \\
\hline Excellent & 68 & $42.77 \%$ & $42.77 \%$ \\
\hline Very good & 16 & $10.06 \%$ & $52.83 \%$ \\
\hline Good & 38 & $23.90 \%$ & $76.73 \%$ \\
\hline Regular & 24 & $15.09 \%$ & $91.82 \%$ \\
\hline Bad & 13 & $8.18 \%$ & $100.00 \%$ \\
\hline Total & 159 & $100.00 \%$ & $100.00 \%$ \\
\hline
\end{tabular}

\section{DISCUSSION}

Language is not an isolated mental activity, it gathers different processes, involving sensory skills, motor, cognitive and language skills and any kind of human limitation that affects one of these aspects may compromise its functionality, manifesting itself on speech process. A symptomatic speech can disturb the sense of self-awareness and disorders of speech autonomy in someone, marginalizing him on his social environment. Thus stigmatization and isolation can happen and affect his speech perception. ${ }^{12}$

The elderly's self-perception on the process of aging and body illness can be influenced by physical, cognitive and emotional health aspects, thus the prevalence of communication disorders found in this study should be considered from this viewpoint. ${ }^{13}$ In this study, the finding of $8.81 \%$ prevalence of self-reported communication difficulty was reported by elderly women, considering the majority aged between 60 and 69 years.

A study found that the functional capacity of elderly participants and language groups of multidisciplinary care detected $10 \%$ of language deficit. Findings related to speech deficit on elderly patients with neurological sequelae deficit showed $47.7 \%$ of prevalence. ${ }^{9,14}$ The deficits described in the literature refer to changes in speech fluency, hesitations, interjections and corrections which increase with advanced age..$^{15-18}$

Although contradictory, the observed changes in elderly's speech, such as reduced use of complex grammatical structures, verbiage, ambiguous use of benchmarks, the central topic digression, repetition of ideas, overinterruptions, hardship lexical access, overlapping voices, shift work changes, hesitations and repetitions can compromise the cohesion and coherence of the speech, justifying the decline of communication aspects perceived by elderly. ${ }^{15,19-21}$.

Beyond characterization of communication disorders perceived by elderly women, it is worth mentioning that the majority did not point the lack of reading and writing domain, referring difficulty by $8.18 \%$ and $5.7 \%$, respectively. Mansur \& Garcia $^{4}$ assessed communicative abilities in healthy elderly people and observed lowest averages on the field of reading, writing and numbers $(5.96 \%)$, emphasizing the influence of education on the performance of elderly in assessments of cognition and language.

It was observed in this study, the association between self-reported communication disorder with hearing loss and educational level. Among the illiterate ones, $20 \%$ reported communication difficulties, while literate indicated $8.44 \%$. Other studies point to a positive association between 
the linguistic decline and cognition, educational level, depression, sex and social relations. ${ }^{3,6,7}$ One study evaluated the influence of educational level and age within adult speech, and verified associations between the study level and the oral comprehension tasks, reading, graphic comprehension, designation, lexical availability, dictation, graphic designation of actions and number reading. ${ }^{22}$

In the current study, the prevalence of selfreported hearing hardship was $17.61 \%$. In a population inquiry conducted in São Paulo city, the findings of self-reported hearing disorders among elderly people were $17.7 \%$, increasing to $41.4 \%$ among the population over 75 years old. ${ }^{23}$ A study performed in the United States with subjects aged 65 and over detected $42 \%$ of hearing problems, $26 \%$ with writing problems and $7 \%$ with phone talking problems, recognizing the severity of communication disorders related to chronic health problems. ${ }^{5}$ Our findings did not find association between communication disorders and morbidities referred to elderly women.

The complaint of lexical access difficulty, in other words, how to find the correct word at the right moment, is a constant issue among the elderly, and this issue must be pointed as the most observed difficulty. ${ }^{24,25}$ The evaluation of statements of elderly identified $11.89 \%$ of meaningless statements related to difficulty in searching and evoking the desired word. ${ }^{26}$ In this study, $10.6 \%$ people referred to lexical access difficulty.

Comprehensionisone of themostcontroversial aspects. Sometimes it is postulated as a process that declines with aging, although some studies disagree in pointing speech production as one of the most affected components. Difficulties related to the coordination of concurrent processes in complex linguistic activities, temporary information storage and oversight of these activities have been mentioned as determinants in misunderstandings. ${ }^{2,27}$ Other studies show significant association between oral speech comprehension outcome with sociodemographic variables: age, educational level and literacy; with the variables of health conditions: hypertension diagnosis, cognitive and mental state; and social relations in self-assessment of comprehension in conversations. ${ }^{7,28,29}$ Data from this study revealed a prevalence of $10.69 \%$ of self-reported difficulty in oral comprehension.

The studies indicate that communication disorders observed in the aging process are mainly caused by motor and sensory impairments, which influence the flexibility and speed of mental processing of information, made up of declines in memory and cognition. ${ }^{30,31}$ Memory is one of the most studied aspects of the elderly population and the findings are questionable. Research works have shown that there is no effect of age on working memory in healthy elderly. ${ }^{4,32}$ The analysis of cognitive functions in healthy elderly revealed that younger and female elderly showed better performance in memory and recall tests, concluding that the deficit in memory may be associated with age and language remains intact in all age groups, despite the best performance associated with education. ${ }^{23,33}$ Authors draw attention to the negative perception that the elderly have on their memory, which can result in low test performance that evaluates this function. ${ }^{34,35}$ The values found in this study detected a prevalence of $38.36 \%$ of memory deficit.

In the results interpretation of the current study it is important to consider some methodological bounds. Measurement was performed by self-perception, and the difficulty of the subjects to realize or admit complaints can overestimate data; moreover, the sample was composed only by women, which does not allow to generalize data on communication disorders, nor conclude on differences in relation to sex, which has been mentioned in the literature. The study also identified the need to prepare speech assessment protocols easily applied to diagnose this situation in epidemiological research. 


\section{CONCLUSION}

In this study, $8.81 \%$ of elderly women reported communication disorder, with significant association on hearing loss and education. The findings aim to contribute to the understanding of phenomena and transformations that occur in the speech at this stage of life, to be able to

\section{REFERENCES}

1. Wright HH, Capilouto GJ, Koutsoftas A. Evaluating measures of global coherence ability in stories in adults. Int J Lang Commun Disord 2013;48(3):249-56.

2. MacKay DG, James LE. Sequencing, speech production, and selective effects of aging on phonological and morphological speech errors. Psychol Aging 2004;19(1):93-107.

3. MacKay DG, Abrams L, Pedrosa MJ. Aging on the input versus output side: theoretical implications of age-linked asymmetries between detecting versus retrieving orthographic information. Psychol Aging 1999;14(1):3-17.

4. Mansur L, Garcia F. Habilidades funcionais de comunicação: idoso saudável. Acta Fisiátrica 2006;13(2):87-9.

5. Yorkston KM, Bourgeois MS, Baylor CR. Communication and Aging. Phys Med Rehabil Clin North Am 2010;21(2):309-19.

6. Martins V, Andrade C. Estudo das pausas em idosos. Rev Soc Bras Fonoaudiol 2011;16(3):344-49.

7. Carvalho S, Barreto S, Guerra H, Gama A. Oral language comprehension assessment among elderly: a population based study in Brazil. Prev Med 2009;49(6):541-5.

8. Santos CP, Ferrari C e Giacheti CM. Perfil funcional da comunicação em idosos institucionalizados: achados preliminares. In: Anais do $17^{\circ}$ Congresso Brasileiro de Fonoaudiolohgia . $1^{\circ}$ Congresso Ibero-Americano de Fonoaudiologia; 21-24 Out. 2009; Salvador; 2009. Rev Soc Bras Fonoaudiol 2009;14Supl:1852.

9. Albuquerque AG, Oliveira GS, Montarroyos VL, Nascimento CB. Capacidade funcional e linguagem de idosos não-participantes e participantes de grupos de intervenção multidisciplinar na atenção primária à saúde. Rev CEFAC 2012;14(5):952-62. comply with the needs of communication aspects of the elderly.

\section{ACKNOWLEDGMENTS}

The authors are grateful to University of the State of Amazonas, University of the Third Age/ UnATI/UEA, Division of Gerontology.
10. Instituto Brasileiro de Geografia e Estatística. Censo 2010 [Internet]. Rio de Janeiro: IBGE; 2010 [acesso em 16 Fev. 2012]. Disponível em: http://censo2010. ibge.gov.br/resultados.

11. Departamento Intersindical de Estatística e Estudos Socioeconômicos. A situação do trabalho no Brasil [Internet]. São Paulo: DIEESE; 2012 [acesso em 16 Fev. 2012]. Disponível em: http://www.dieese.org.br/ livro/2012/livroSituacaoTrabalhoBrasil.pdf.

12. Lier-de-Vito MF, Fonseca SC, Landi R. Vez e voz na linguagem: o sujeito sob efeito de sua fala sintomática. Rev Kairós 2007;10(1):19-34.

13. Alves LS, Rodrigues RN. Determinantes da autopercepção de saúde entre idosos do Município de São Paulo, Brasil. Rev Panam Salud Pública 2005;17(5/6):333-41.

14. Remesso GC, Chiappetta ALML, Aguiar AS, Fukujima MM, Prado GF. Verbal language spontaneous recovery after ischemic stroke. Arq Neuropsiquiatr 2009;67(3b):856-9.

15. Tubero AL. A linguagem do envelhecer: saúde e doença. Distúrb Comun 1999;10(2):167-76.

16. Snitz BE, Unverzaqt FW, Chang CC, Bilt JV, Gao S, Saxton J, et al. Effects of age, gender, education and race on two tests of language ability in communitybased older adults. Int Psychogeriatr 2009;21(6):105162.

17. Findlay L, Bernier J, Tuokko H, Kirkland S, Gilmour $\mathrm{H}$. Validation of cognitive functioning categories in the Canadian Community Health Survey - Healthy Aging. Health Rep 2010;21(4):85-100.

18. Fagnani C, Fibiger S, Skytthe A, Hjelmborg JVB. Heritability and environmental effects for selfreported periods with stuttering: a twin study from Denmark. Logop Phoniatr Vocol 2011;36(3):114-20. 
19. Barratt J, Khoza-Shangase K, Msimang K. Speechlanguage assessment in a linguistically diverse setting: preliminary exploration of the possible impact of informal 'solutions' within the South African context. S Afr J Commun Disord 2012; 59(1):34-44.

20. Leyton CE, Hsieh S, Mioshi E, Hodges JR. Cognitive decline in logopenic aphasia: more than losing words. Neurology 2013;80(10):897-903.

21. Rabadan O, Pereiro A, Rodriguez M. Narrative speech in aging: quantity, information content, and cohesion. Brain Lang 2005;95(3):423-34.

22. Souza ECS, Ortiz K. Influence of schooling on language abilities of adults without linguistic disorders. São Paulo Med J 2009;127(3):134-9.

23. Cruz MS, De Oliveira LR, Carandina L, Lima MCP, Chester LGC, Barros MBA, et al. Prevalência de deficência auditiva referida e causas atribuídas: um estudo de base populacional. Cad Saúde Pública 2009;25(5):1123-31.

24. Gomes MCS, Garcia VL. Estudo sobre a linguagem oral do idoso. Mimesis 2006;27(1):69-78.

25. Lin FR, Yaffe K, Jin X, Quian-Li X, Harris TB, Purchase-Helzne E, et al. Hearing Loss and cognitive decline in older adults. JAMA Intern Med 2013;173(4):293-99.

26. Garcia VL, Rodolfo SM. A linguagem do idoso: aspectos da anamnese e avaliação fonoaudiológica. Mimesis 1995;16(1):1-12.

27. Bonini MV, Mansur LL. Comprehension and storage of sequentially presented radio news items by healthy elderly. Dement Neuropsychol 2009;3(2):118-23.
28. Baken RJ, Orlikoff RJ. Clinical Measurement of Speech and Voice. 2nd ed. United States of America: Singular Thomson Learning; 2000.

29. Perez-Diaz AGL, Calero MD, Navarro-Gonzalez E. Prediction of cognitive impairment in the elderly by analysing their performance in verbal fluency and in sustained attention. Rev Neurol 2013;56(1):1-7.

30. Baraldi G, Borges A, Almeida L. Evolução da perda auditiva no decorrer do envelhecimento. Rev Bras Otorrinolaringol 2007;73(1):64-70.

31. Carmo LC, Da Silveira JAM, Marone SAM, D’Ottaviano FG, Zagati LL, Lins EMDS. Estudo audiológico de uma população idosa brasileira. Rev Bras Otorrinolaringol 2008;74(3):342-49.

32. Hommet C, Perrier D, Beaufils E, Constans T, Mondon K. Language disorders and neurodegenerative pathologies. Soins, Gerontol 2012;(96):16-20.

33. Souza VL, Borges MF, Vitória CMS, Chiappetta ALML. Perfil das habilidades cognitivas no envelhecimento. Rev CEFAC 2010;12(2):186-92.

34. Coelho FGM, Vital TM, Novais IP, Costa GA, Stella F, Santos-Galduroz RF. Desempenho cognitivo em diferentes níveis de escolaridade de adultos e idosos ativos. Rev Bras Geriatr Gerontol 2012;15(1):7-15.

35. Freitas DHM, Campos FCA, Linhares LQ, Santos CR, Ferreira CB, Diniz BS, Tavares A. Autopercepção da saúde e desempenho cognitivo em idosos residentes na comunidade. Rev Psiquiatr Clín 2010;37(1):32-5. 